\title{
SINDROM TOLOSA HUNT DENGAN KETERLIBATAN SARAF OPTIKUS
}

\author{
TOLOSA HUNT SYNDROME WITH OPTIC NERVE INVOLVEMENT
}

Astra Dea Simanungkalit, * Maria Larasati Susyono, ** Vivien Puspitasari*

\section{ABSTRACT}

Tolosa Hunt syndrome (THS) is a very rare clinical syndrome, which is characterized by unilateral headaches accompanied by dysfunction and painful ophthalmic nerves. In some cases, optic nerve involvement can be found due to inflammation at the orbital apex. Corticosteroid administration is a management of THS with pain relief generally occurring in the first 72 hours. However, corticosteroid administration is not significantly associated with nerve dysfunction or visual acuity improvement.This article is a case report of women with STH and optic nerve involvement.

Keywords: Tolosa Hunt syndrome, painful ophtalmoplegia, orbital apex, superior orbital fissure

\begin{abstract}
ABSTRAK
Sindrom Tolosa Hunt (STH) adalah sindrom klinik yang sangat jarang, yang ditandai oleh nyeri kepala unilateral disertai disfungsi dan nyeri saraf penggerak bola mata (painful ophtamloplegia). Pada beberapa kasus, dapat ditemukan keterlibatan saraf optikus akibat inflamasi pada apeks orbita. Pemberian kortikosteroid merupakan tatalaksana STH dengan perbaikan nyeri umumnya terjadi pada 72 jam pertama. Meskipun demikian pemberian kortikosteroid tidak berhubungan secara signifikan dengan perbaikan disfungsi saraf penggerak bola mata maupun tajam penglihatan. Artikel ini merupakan laporan kasus perempuan dengan STH dan keterlibatan saraf optikus.
\end{abstract}

Kata kunci: Sindrom Tolosa Hunt, painful ophtalmoplegia, apeksorbita, fisura orbitalis superior

*Departemen Neurologi Universitas Pelita Harapan-Siloam Hospitals Lippo Village, Banten, Indonesia; **Departemen Ilmu Kesehatan Mata Universitas Pelita Harapan-Siloam Hospitals Lippo Village, Banten, Indonesia. Korespondensi: simanungkalit.astra@gmail.com.

\section{PENDAHULUAN}

Sindrom Tolosa Hunt (STH) adalah sindrom klinik yang ditandai oleh nyeri kepala unilateral yang disertai disfungsi dan nyeri saraf penggerak bola mata (painful ophthalmoplegia). Sindrom ini pertama kali dilaporkan secara terpisah oleh dr. Eduardo Tolosa pada tahun 1954 dan Hunt dkk pada tahun 1961, namun penyebutan Tolosa Hunt baru pertama kali mucul pada literatur yang ditulis oleh Smith dan Taxdal pada tahun $1966 .^{1}$

STH merupakan kelainan yang sangat jarang ditemukan dengan insidens hanya satu per sejuta kasus tiap tahunnya. Saraf okulomotor (saraf kranial III) merupakan saraf yang paling banyak terkena pada sindrom ini, meskipun demikian keterlibatan saraf troklear dan abdusen (saraf kranial IV dan VI), bahkan saraf trigeminal (saraf kranial V) juga dapat ditemukan. Pada kasus yang sangat jarang dapat terjadi inflamasi pada apeks orbita yang mengakibatkan kerusakan pada saraf optikus, yaitu hanya sekitar 6\% STH. Derajat gangguan penglihatan yang ditemukan pada kasus seperti ini sangat bervariasi dan dapat bersifat permanen. ${ }^{1-2}$
Laporan kasus ini melaporkan kasus STH pada seorang perempuan usia muda dengan keterlibatan saraf optikus yang permanen, bahkan setelah pemberian kortikosteroid.

\section{KASUS}

Seorang perempuan berusia 44 tahun, datang ke poliklinik saraf dengan keluhan utama gangguan penglihatan pada mata kiri sejak 2 minggu sebelumnya. Keluhan ini diawali dengan nyeri diikuti ketidakmampuan mengangkat kelopak mata kiri dan menggerakkan bola mata kirinya yang semakin memberat sejak 1 minggu sebelumnya. berupa. Nyeri dirasakan di daerah sekitar mata, pegal, kadang disertai rasa berdenyut. Derajat nyeri berdasarkan numeric rating scale (NRS) sekitar 8/10 yang tidak membaik dengan obat analgetik.

Selanjutnya pandangan terasa buram yang bertambah berat pada mata kiri dalam 2 minggu, disertai kelopak mata makin menutup, sehingga pasien lebih banyak menggunakan mata kanannya. Pasien baru menyadari mata kirinya tidak dapat melihat 1 hari sebelum pasien datang ke rumah sakit. 
Pada pemeriksaan fisik didapatkan adanya visus 0 pada mata kiri dan paresis nervus III,IV,VI kiri total, serta lesi nervus V1 (Gambar 1). Funduskopi didapatkan gambaran papil hiperemis dengan batas tidak tegas, rasio arteri:vena 1:3 pada mata kiri yang sesuai dengan papiledema. Tidak ditemukan tandatanda peningkatan tekanan intrakranial, keterlibatan saraf kranial maupun defisit neurologis lainnya.
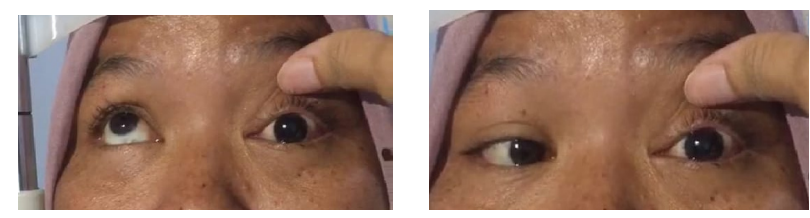

Gambar 1. Oftalmopegia dengan Ptosis Mata Kiri

Hasil pemeriksaan laboratorium darah lengkap dalam batas normal, tidak ada peningkatan sel leukosit maupun laju endap darah (LED) yang menunjukkan tanda-tanda infeksi maupun inflamasi. Direncanakan pemeriksaan pungsi lumbal, namun pasien menolak. Pemeriksaan magnetic resonance imaging (MRI) kepala dengan kontras menunjukkan adanya lesi isointens pada $\mathrm{T} 1$, hipointens pada $\mathrm{T} 2$ dan menyangat pascakontras sugestif suatu inflamasipada fisura orbita superior kiri (Gambar 2), yang sesuai dengan gambaran sindrom Tolosa Hunt.
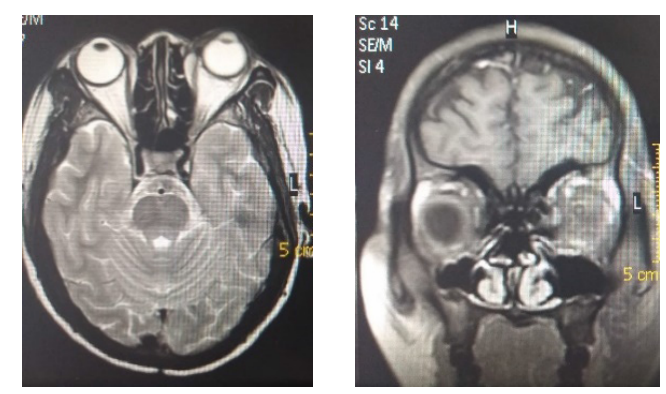

Gambar 2. Magnetic Resonance Imaging Kepala dengan Kontras Potongan Aksial dan Koronal Menunjukkan Inflamasi pada Fisura Orbitalis Superior

Pasien dirawat dan mendapat terapi kortikosteroid Deksametason 20mg/hari selama 1 minggu, lalu diturunkan perlahan. Terdapat perbaikan nyeri secara signifikan sejak hari kedua terapi, namun tidak ada perbaikan defisit neurologis lainnya. Pasien dipulangkan setelah 2 minggu perawatan, dengan terapi prednison $60 \mathrm{mg} /$ hari yang diturunkan bertahap pada rawat jalan. Saat pulang tidak ada keluhan nyeri sama sekali dan mulai mampu mengangkat kelopak mata kiri, namun belum ada perbaikan tajam penglihatan dan gerakan bola mata. Perbaikan ptosis ini masih didapatkan (Gambar 3) pada saat pasien kontrol satu minggu setelah perawatan (minggu kelima onset).
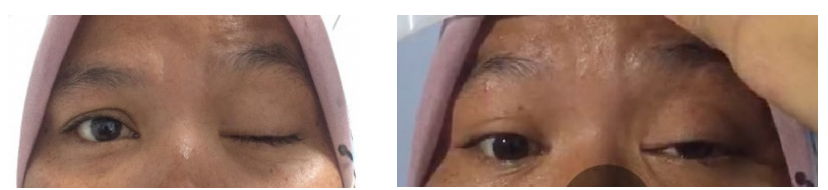

Gambar 3. Perbaikan Ptosis Mata Kiri dari Saat Masuk (Kiri) dan Sesudah Perawatan (Kanan).

\section{PEMBAHASAN}

Pada kasus ini diagnosis STH ditegakkan berdasarkan adanya nyeri kepala unilateral pada area periorbita yang terjadi simultan dengan kelemahan pada satu atau lebih saraf penggerak bola mata (saraf kranialis III,IV, dan VI). Gejala ini disebabkan oleh peradangan granulomatosa pada fisura orbitalis superior yang sesuai dengan gambaran MRI kepala. Hal ini sesuai dengan kriteria diagnosis International Headache Society (IHS) dan Konsensus Nyeri Kepala Perhimpunan Dokter Spesialis Saraf Indonesia (PERDOSSI) untuk sindrom Tolosa Hunt. ${ }^{3-4}$

STH disebabkan oleh adanya proses inflamasi nonspesifik yang ditandai oleh infiltrasi limfosit, dan sel plasma, serta pembentukan granuloma sel raksasa (giant cell granuloma) dan proliferasi fibroblas yang belum jelas penyebabnya pada dinding dan septa sinus kavernosus. Inflamasi ini akan mengakibatkan gangguan pada saraf-saraf kranialis III,IV, dan VI yang berjalan di dalam sinus kavernosus. Adanya keterlibatan saraf Trigeminal cabang oftalmikus (V1) dan Maksilaris (V2), menunjukkan inflamasi yang berlanjut ke arah anterior, mencapai fisura orbitalis superior. Bila terjadi perluasan inflamasi ke superomedial hingga mencapai apeks orbita, akan mengakibatkan gangguan pada saraf optikus (N. II). ${ }^{5}$

Pada pemeriksaan funduskopi pasien ini ditemukan gambaran papiledema. Hal ini dapat ditemukan pada STH dengan inflamasi yang mencapai apeks orbita, sehingga terjadi obstruksi pada aliran keluar vena dan gambaran papiledema. Penurunan tajam penglihatan yang diakibatkan dapat bervariasi, mulai dari minimal hingga kebutaan seperti pada pasien ini. Minimnya jumlah kasus 
membuat patofisiologi, faktor yang mengakibatkan perluasan inflamasi maupun respons perbaikan defisit neurologis yang berbeda-beda terhadap pemberian kortikosteroid, hingga saat ini belum dipahami dengan baik. Dari laporan kasus yang ada, defisit neurologis pada STH masih dapat mengalami perbaikan bahkan hingga 10 bulan setelah onset. Pada pasien ini, tidak adanya perbaikan visus setelah pemberian kortikosteroid secara klinis menunjukkan prognosis yang buruk. ${ }^{6-8}$

MRI kepala khususnya potongan koronal merupakan modalitas pencitraan utama dalam menegakkan diagnosis STH berupa gambaran inflamasi pada fisura supraorbital kiri sesuai dengan pasien ini. Selain untuk melihat inflamasi di daerah sinus kavernosus dan fisura orbitalis superior, pemeriksaan MRI juga dibutuhkan untuk menyingkirkan kelainan pada sinus kavernosusdan parasela yang dapat memiliki gejala serupa. Pada kecurigaan ke arah gangguan vaskular, harus dilakukan pemeriksaan CT angiografi maupun MR angiografi. ${ }^{6}$

Pada pasien ini, pemeriksaan laboratorium darah tidak menunjukkan hasil yang abnormal, namun beberapa literatur melaporkan peningkatan LED dan leukositosis tanpa adanya fokus infeksi yang jelas pada STH. Pemeriksaan pungsi lumbal juga merupakan salah satu pemeriksaan untuk menyingkirkan kemungkinan infeksi bakterial maupun viral. Hasil yang normal menunjang ke arah STH, meskipun pada beberapa kasus, didapatkan sedikit peningkatan protein dan sel yang memberikan respons pada pemberian kortikosteroid. ${ }^{6}$

Diagnosis STH merupakandiagnosis yang ditegakkan setelah menyingkirkan etiologi lain. Kelainan di daerah sinus kavernosus dan parasela seperti aneurisma, neoplasma dan infeksi; serta kelainan lain dengan manifestasi klinis yang menyerupai STH seperti oftalmoplegia diabetikum, giant cell arteritis dan migrain ophtalmoplegia harus disingkirkan terlebih dahulu sebelum diagnosis STH dapat ditegakkan. ${ }^{6,8}$

Pemberian kortikosteroid merupakan tatalaksana STH. Nyeri akan mengalami perbaikan secara dramatis dalam 24-72 jam, namun belum ada bukti yang mendukung hubungan antara pemberian kortikosteroid dengan perbaikan disfungsi saraf penggerak bola mata. Pada pasien, pemberian kortikosteroid (deksametason) 20mg/hari intravena memberikan respons pengurangan nyeri yang signifikan. Adanya perbaikan pada ptosis juga terlihat pada pemberian kortikosteroid selama perawatan. Pergerakan bola mata pasien pada saat pulang masih sangat terbatas. Pada kasus demikian kortikosteroid oral dengan dosis $1 \mathrm{mg} / \mathrm{kgBB}$ dan kemudian diturunkan bertahap dapat dilanjutkan sesuai respons klinis pasien. ${ }^{6-8}$

Kebanyakan kasus STH mengalami remisi dengan pemberian kortikosteroid dalam beberapa hari hingga 8 minggu. Defisit neurologis yang permanen merupakan hal yang sangat jarang terjadi setelah pemberian kortikosteroid. Pada kasus yang tidak memberikan respons dengan pemberian kortikosteroid, beberapa laporan kasus menyarankan pemberian imunosupresan, seperti cyclosporine, azathioprine dan methotrexate. ${ }^{6-8}$ Pasien ini tidak mendapatkan terapi tersebut karena keterbatasan biaya.

Pada beberapa kasus STH, terutama pada pasienusia muda, terjadi rekurensi kasus 40$50 \%$ dalam jangka waktu beberapa bulan hingga beberapa tahun. Meskipun belum ditemukan adanya hubungan yang jelas dengan penyakit autoimun tertentu, STH juga dilaporkan terjadi pada pasien dengan kelainan autoimun seperti lupus eritematosus sistemik, sarcoidosis, dan granulomatosis Wegener's. Rekurensi ini dapat terjadi pada mata yang sama (ipsilateral) maupun pada mata kontralateral maupun bilateral (pada kasus yang lebih jarang) ${ }^{8-9}$ Pasien ini masih dimungkinkan terjadinya rekurensi, sehingga penting dilakukan edukasi mengenai risiko rekurensi serta pentingnya diagnosis dan terapi sedini mungkin.

\section{KESIMPULAN}

Sindrom Tolosa Hunt merupakan sindrom yang jarang ditemukan, apalagi hingga melibatkan saraf optik. Sindrom ini bersifat idiopatik, sehingga etiologi lain harus disingkirkan sebelum penegakkan diagnosisnya. Pemberian kortikosteroid dapat meng- 
hilangkan keluhan nyeri dan memperbaiki defisit neurologis yang terjadi, namun tidak mencegah rekurensi.

\section{DAFTAR PUSTAKA}

1. Borooah M, Ekka J, Ghosh D. Tolosa-Hunt syndrome: a rare case report. IOSR-JDMS. 2018;17(3):40-3.

2. Lasam G, Kapur S. A rare case of tolosa-Hunt-like syndrome in a poorly controlled diabetes mellitus. Case rep med. 2016;2016:9763621.

3. Headache Classification Committee of the International Headache Society (IHS). The international classification of headache disorders. Edisi Ke-3. Cephalalgia. 2013;33(9):629-808.

4. PERDOSSI. Neuralgia kranial, sentral, atau nyeri fasial primer dan nyeri kepala lainnya. Konsensus Nasional V Kelompok Studi Nyeri Kepala PERDOSSI
2018. Surabaya: Airlangga University Press Surabaya; 2018.

5. Badakere A, Patil-Chhablani P. Orbital apex syndrome: a review. Eye Brain. 2019;11:63-7.

6. Kline LB, Hoyt WF. The Tolosa-Hunt syndrome. J Neurol Neurosurg Psychiatry. 2001;71:577-82.

7. Zhang X, Zhang W, Liu R, Dong Z, Yu S. Factors that influence Tolosa-Hunt syndrome and the short-term response to steroid pulse treatment. J Neurological Sci. 2014;341:13-6.

8. Junior MNS, Silva AE, Bonatti RCF. Tolosa Hunt syndrome, a painful ophthalmoplegia. Rev Bras Oftalmol. 2019;78(4):271-3.

9. Carreóna E, Muñizb S, Capuab DD, Porta-Etessam J. Tolosa-Hunt syndrome with spontaneous remission and recurrence. Neurologia. 2018;33:68-70. 